\title{
Avaliação do comportamento de metals pesados no TRATAMENTO DE ESGOTOS POR DISPOSIÇÃO NO SOLO
}

\author{
ASSESSMENT OF THE BEHAVIOR OF HEAVY METALS IN THE SEWAGE \\ TREATMENT BY DISPOSAL IN SOIL
}

\begin{abstract}
WANDERLEY DA SilVA PAGANINI
Mestre e doutor em Saúde Pública pela Faculdade de Saúde Pública da Universidade de São Paulo. Professor Doutor do

Departamento de Saúde Ambiental da Faculdade de Saúde Pública da Universidade de São Paulo
\end{abstract}

\begin{abstract}
ADRIANA DE SOUZA
Bióloga e mestranda em Saúde Pública do Departamento de Saúde Ambiental, Faculdade de Saúde Pública da

Universidade de São Paulo
\end{abstract}

\section{MIRIAM MoREIRA BOCCHIGLIERI}

Engenheira e mestranda em Saúde Pública do Departamento de Saúde Ambiental, Faculdade de Saúde Pública

da Universidade de São Paulo

Recebido: 29/12/03 Aceito: 09/06/04

\section{RESUMO}

Este trabalho apresenta os níveis de contaminação do solo por metais pesados, decorrentes de 16 anos de operação da Estação de Tratamento de Esgotos, por escoamento à superfície, localizada no município de Populina (São Paulo). As análises realizadas para esta avaliação envolveram o $\mathrm{pH}$ e os seguintes metais pesados cobre, zinco, alumínio, cádmio, mercúrio, molibdênio, níquel e chumbo. Os resultados mostraram que a grande maioria dos metais apresentou comportamento semelhante, com concentrações consideráveis até 30 e $50 \mathrm{~m}$ de distância do ponto de lançamento, nos primeiros $20 \mathrm{~cm}$ de profundidade. Deverão ser realizadas novas pesquisas devido aos valores elevados de $\mathrm{Hg}, \mathrm{Ni}$, $\mathrm{Pb}$ e Al registrados a $20 \mathrm{~m}$ de distância do ponto de lançamento dos esgotos, pois se isto for confirmado existem grandes riscos de contaminação dos lençóis subterrâneos.

PALAVRAS-CHAVE: Escoamento à superfície, esgoto bruto, metais pesados, solo, efeitos no solo.

\begin{abstract}
This assay presents the soil contamination levels by heavy metals, from 16 years of a sewage plant operation, by overland flow, in Populina City, São Paulo State, Brazil. The analyses carried out for this evaluation were the $\mathrm{pH}$ and the following heavy metals: copper, zinc, aluminum, cadmium, mercury, molybdenum, nickel and lead. The results showed that the majority of the metals presented similar behavior, with considerable concentration up to 30 and $50 \mathrm{~m}$ of distance from the launching spot, concentrated on the first $20 \mathrm{~cm}$ of depth. The dumping from gas stations on the sewage collecting system seems to contribute to the increase of the lead levels. New researches should be carried out due to the high values of $\mathrm{Hg}, \mathrm{Ni}, \mathrm{Pb}$ and $\mathrm{Al}$ registered $20 \mathrm{~m}$ far from the sewage launching spots, because if it is confirmed there will be high contamination risks to the table waters.
\end{abstract}

KEYWORDS: Heavy metal, overland flow, sewage, soil, soil effects.

\section{INTRODUÇÃO}

A urbanização levou a implantação dos sistemas públicos de coleta de esgotos, ampliando-se a disposição dos mesmos nos corpos d'água, permanecendo ausente qualquer preocupação maior com o lançamento "in natura” e o processo natural de autodepuração dos corpos receptores. A deterioração ambiental provocada por esta prática fez com que as atenções se voltassem para a depuração e a disposição de esgotos no solo. A aplicação dos esgotos no solo pode ocorrer por um dos seguintes processos: irrigação, in- filtração-percolação e escoamento à superfície. Neste último processo, o afluente é lançado na parte superior de um plano inclinado por meio de aspersores ou através de tubos perfurados, sendo a parcela líquida efluente recolhida na parte inferior através de canais de drenagem que transportam o líquido tratado ao corpo receptor. O tratamento, portanto, é obtido à medida que os esgotos avançam no plano inclinado.

A exemplo do que acontece nos processos naturais de autodepuração dos corpos de água, os esgotos brutos ou tratados, ao serem lançados no solo, têm sua carga poluidora diminuída por processos físicos, químicos e biológicos. Para compreendê-los, é preciso ter presente que o solo é mais do que um simples meio físico formado por substâncias minerais e orgânicas que, juntamente com a vegetação superior, a energia solar e a água, assegura a continuidade de um dos ciclos mais importantes da natureza, que é a transformação da matéria orgânica em energia renovável (Paganini, 2003).

A aplicação de esgotos no solo é vista como uma forma efetiva de controle da poluição e uma alternativa viável para aumentar a disponibilidade hídrica em 
regiōes áridas e semi-áridas, sendo os maiores benefícios dessa tecnologia os aspectos econômicos, ambientais e de saúde pública. Porém, muitos aspectos e detalhes devem ser considerados, por serem de interesse agrícola e sanitário: os riscos da salinidade, da contaminação por metais pesados, da contaminação biológica, e por fim, a potencialidade deletéria da lixiviação de elementos através do solo até os lençóis subterrâneos.

A disposição no solo de esgotos com altos teores de metais pesados deve ser avaliada com critério. Sua acumulação ao longo do perfil vertical do solo pode propiciar fitotoxicidade às plantas, além de constituir risco à saúde humana, na medida em que esses metais podem ser introduzidos na cadeia alimentar. (Paganini, 2003).

O objetivo deste trabalho é detectar os níveis de contaminação do solo, por metais pesados, da Estação de Tratamento de Esgotos de Populina, cujo método de disposição é por escoamento superficial, após 16 anos de operação do sistema.

\section{O COMPORTAMENTO DOS METAIS NO SISTEMA SOLO-PLANTA}

\section{Cobre e zinco}

O cobre e o zinco, teoricamente em concentraçôes acima de $10 \mathrm{mg} / \mathrm{L}$ podem vir a ser tóxicos às plantas. Como o zinco e outros metais, a toxicidade do cobre disposto no solo é, também, influenciada pelo $\mathrm{pH}$ e pela quantidade de matéria orgânica contida no mesmo. O cobre é menos prontamente translocado para a planta do que o zinco, e pode se acumular em altas concentrações nas raízes. Nos cereais, por exemplo, ele restringe o crescimento das raízes, produzindo múltiplas ramificações inchadas. Muito embora possa ser absorvido e concentrado nos sistemas radiculares, o cobre não é transportado em altas concentrações para a parte aérea das plantas (Driver et al., 1972; MatiazzoPrezotto, 1994; Underwood, 1978).

O cobre se move vagarosamente no solo, como um complexo orgânico, e permanece na superfície do mesmo. Os solos com concentraçôes representativas de cobre podem ser desintoxicados com a adição de calcário, mantendo-se o pH acima de 6,5. A contaminação dos solos por cobre é rara, exceto quando se faz a disposição de efluentes de atividades agrícolas, onde o elemento é largamente utilizado como fungicida. Outros metais no solo (ferro, manganês, alumínio, etc.) afetam a disponibilidade de cobre para o crescimento das plantas, e este efeito independe do tipo de solo (Williams, 1975; EPAV, 1980; Potafos, 1998).

Grande quantidade de zinco pode ser fixada na fração orgânica do solo. Ele pode também ser temporariamente imobilizado nos microrganismos quando se adiciona matéria orgânica ao solo; por outro lado, grande parte do zinco disponível em um solo mineral está associada com a matéria orgânica. Baixos níveis de matéria orgânica em solos minerais são, freqüentemente, indicativos de baixa disponibilidade de zinco (Ramachandran e D’Souza, 1998; Tsai e Vesilind, 1998).

\section{Alumínio}

O alumínio pode causar quebra na produtividade de culturas em solos ácidos, com $\mathrm{pH}<5,5$, porém, em solos mais alcalinos, com $\mathrm{pH}<7,0$, poderá precipitar-se e eliminar a toxicidade.

O alumínio tem um papel importante na fixação do fósforo em solos bem drenados. A forma na qual o alumínio aparece em solos aerados depende, fortemente, do $\mathrm{pH}$ do solo. Em solos com $\mathrm{pH}=4,0$, ele existe como o íon $\mathrm{Al}^{+3}$; com a elevação do $\mathrm{pH}$ para 4,9 , o elemento converte-se para $\mathrm{Al}(\mathrm{OH})^{+2}$ e $\mathrm{Al}(\mathrm{OH})_{2}{ }^{+}$e, finalmente, $\mathrm{a}(\mathrm{AlOH})_{3}$ quando o $\mathrm{pH}$ atinge valores acima de 5,0 . As três primeiras formas de alumínio ativado são capazes de fixar o fósforo. As concentrações tóxicas do alumínio solúvel nos solos que influenciam negativamente o crescimento das culturas podem ser evitadas com a adição de calcário mantendo, assim, o pH acima de 5,0 (Carlson et al., 1974; Kandiah, 1985).

Não existem muitas pesquisas a respeito do efeito do alumínio sob condições de solo alagado; entretanto, este elemento não parece ser sensível ao fenômeno redox. Até que os valores do $\mathrm{pH}$ dos solos alagados mantenham-se acima de 5,0, o alumínio não deverá tornar-se solúvel o suficiente para ser tóxico à vegetação (Carlson et al., 1974; Gheyi et al., 1997).

\section{Cádmio}

Diferentemente de outros elementos, o cádmio não é um elemento essencial para o crescimento da planta. É usualmente tóxico às plantas em baixas concentrações. Mesmo antes de qualquer sistema ser detectado, o cádmio adicionado ao solo é, rápida e prontamente, absorvido pelas plantas, aumentando drastica- mente o nível do elemento acumulado. Entretanto, a tolerância aos níveis de cádmio adicionado ao solo apresenta grande variabilidade de espécie para espécie. A adição máxima deste elemento recomendada pela Environmental Protection Agency - EUA, através da disposição de lodo ao solo, é de $0,50 \mathrm{~kg} / \mathrm{ha} / \mathrm{ano}$. Para a disposição de esgotos no solo, com uma taxa de aplicação superficial média de $500 \mathrm{~mm} /$ ano, a concentração recomendada pode alcançar, no máximo, $0,10 \mathrm{mg} / \mathrm{L}$. Deve-se salientar que este metal pesado é considerado, pela mesma agência, como podendo vir a ser um fator limitante para a aplicação de esgotos no solo (EPAV, 1983; EPAV, 1991; Matiazzo-Prezotto, 1994; Williams, 1975).

\section{Mercúrio}

O mercúrio ocorre largamente na biosfera, e é amplamente conhecido como um elemento tóxico. Desenvolvimentos tecnológicos modernos são responsáveis pela descarga de quantidades representativas deste elemento, no meio ambiente, de diversas formas. A grande maioria do mercúrio existente nos esgotos e nos lodos das estações de tratamento é oriunda das indústrias de tintas, de vernizes, de materiais fotográficos, e de defensivos agrícolas, dentre outros.

Compostos de mercúrio reagem com o solo e podem volatilizar parte do elemento mercúrio; entretanto, devido à grande afinidade entre o metal e o solo, e também pela adsorção do mercúrio à matéria orgânica, ele não tem a tendência de ser lixiviado, mantendo os lençóis subterrâneos, em condiçōes normais, isentos desta contaminação. Altas concentrações de mercúrio no solo podem afetar as plantas, mas isto não ocorre normalmente, nas atividades de aplicação de esgotos e lodos no solo. Pesquisas realizadas em fazendas no nordeste da Europa revelaram que as concentrações nos tecidos das plantas estavam na faixa de 0,02 a $0,08 \mathrm{mg} / \mathrm{kg}$ de matéria seca. Mesmo em campos onde foi executada aplicação por muito tempo de lodos de esgotos, na quantidade de $4 \mathrm{~kg} / \mathrm{ha}$ de mercúrio, as folhas de milho não apresentaram concentraçōes maiores que $0,07 \mathrm{mg} / \mathrm{kg}$ de matéria seca (McBride, 1998; Underwood, 1978).

Em geral, as concentrações de mercúrio encontradas nos esgotos, principalmente domésticos, não são concentrações que causam efeitos danosos, ou cumulativos nas plantas e, portanto, com raras possibilidades de entrar na cadeia alimen- 
tar, o que não é o caso dos peixes contaminados pelo mercúrio encontrado nos cursos d'água. (Gupta e Gupta, 1998; National Research Council, 1996; Williams, 1975).

No tratamento dos esgotos por disposição no solo por escoamento à superfície, a redução mínima obtida no sistema é de $50 \%$, sem apresentar efeito cumulativo, conforme demonstra o sistema de disposição da fazenda de Werribee, na Austrália, em seus 110 anos de existência, tratando esgotos domésticos juntamente com esgotos de atividade industrial da região metropolitana de Melbourne (Melbourne Water Corporation, 1994; Paspaliaris e Hodgson, 1993).

\section{Molibdênio}

Grandes quantidades de molibdênio podem ser adicionadas ao solo com pequeno efeito no crescimento das plantas. O molibdênio aplicado ao solo é prontamente absorvido pelas culturas, e sua disponibilidade às mesmas cresce com a elevação do $\mathrm{pH}$. Como um micronutriente, o metal é requerido em pequenas quantidades pelas plantas, e é essencial, em baixas concentraçôes, na dieta dos animais. Este metal é essencial ao organismo humano em quantidades traço, por participar da molécula de várias metaloenzimas, tais como a xantinoxidase. Considerado relativamente não tóxico, em altas concentraçôes pode causar distúrbios como a astralgia. Para alguns animais, particularmente os ruminantes, concentraçôes baixas como $5 \mathrm{mg} / \mathrm{kg}$ na alimentação podem vir a ser tóxicas (EPAV, 1991; EPVA, 1980; Kandiah, 1985; Mancuso, 1988).

O molibdênio torna-se mais disponível à medida que o $\mathrm{pH}$ aumenta, o oposto do que ocorre com os outros micronutrientes; assim, as deficiências de molibdênio são mais comuns em solos ácidos. Os solos arenosos apresentam mais problemas de deficiência de molibdênio do que os solos argilosos (EPAV, 1991; Potafos, 1998).

\section{Níquel}

O níquel apresenta níveis tóxicos para algumas plantas já a partir de $0,5 \mathrm{mg} / \mathrm{L}$ de concentração. Experiências efetuadas com plantações de aveia relatam sintomas de toxidez a partir da concentração de $2,5 \mathrm{mg} / \mathrm{L}$ de níquel na solução nutriente, bem como marcante redução no crescimento quando esta concentração alcança limites de 5,0 mg/L.
Os efeitos da toxidez, pelos níveis elevados da concentração do níquel, mostram-se nas plantas por dois sistemas distintos, um específico que apresenta listras longitudinais nas folhas e, o outro, uma severa e completa clorose (ausência de clorofila) das áreas interveniais, características da deficiência de ferro. A sensibilidade ao níquel também varia, consideravelmente, de planta para planta (Al-Wabel et al., 1998; Kandiah, 1985; MatiazzoPrezotto, 1994; Williams, 1975).

\section{Chumbo}

Nas plantas, o chumbo pode inibir o crescimento celular quando absorvidas altas concentrações, muito embora, mesmo em solos altamente contaminados, não tenham sido observados efeitos fitotóxicos em concentrações de até $200 \mathrm{mg} / \mathrm{L}$ de chumbo solúvel acrescentado ao solo (AlWabel et al., 1998; Kandiah, 1985).

Estudos realizados em Washington indicaram que a maior parte do chumbo disposto no solo reverte-se na forma não trocável e permanece nos primeiros $15 \mathrm{~cm}$ de profundidade, sendo que um pequeno percentual pode vir a lixiviar de forma lenta e a profundidades não significantes. O chumbo é fixado no solo, porém não mobilizado prontamente; determinados solos podem reter concentraçôes de centenas de $\mathrm{mg} / \mathrm{L}$ contra concentrações de poucas unidades de $\mathrm{mg} / \mathrm{L}$ lixiviados (Driver et al., 1972; Verma et al., 1984).

As plantas não transportam consideráveis quantidades de chumbo para as partes superiores. O sistema radicular de uma planta pode conter concentraçôes de centenas de $\mathrm{mg} / \mathrm{L}$, enquanto que o sistema foliar da mesma, raramente conterá mais de $10 \mathrm{mg} / \mathrm{L}$. Análises realizadas em Washington puderam atestar concentraçôes consideráveis nos sistemas foliares de culturas, porém advindas de fontes aéreas por deposição, principalmente em locais próximos a auto-estradas com tráfego intenso (Jensen et al., 1999; Underwood, 1978; Verma et al., 1984).

\section{METODOLOGIA}

\section{Estação de tratamento de esgotos de Populina}

O sistema pesquisado recebe os esgotos do centro urbano do município de Populina (Figura 1), ininterruptamente, desde julho de 1984. Este município localiza-se a noroeste do Estado de São Paulo
(Brasil), na bacia hidrográfica do Rio Turvo - Grande, distando $625 \mathrm{~km}$ da capital do Estado, tendo acesso pelas rodovias SP-310 eSP-320, sucessivamente (Paganini, 1997).

A população total do município, no censo de 2000, foi de 4433 habitantes contando, atualmente, com 1296 ligações de água e 1173 ligações de esgoto. A temperatura média no município é de $32^{\circ} \mathrm{C}$ nas estaçôes quentes do ano, e de $24^{\circ} \mathrm{C}$ nas estações mais frias.

O sistema está operando acima do limite para o qual foi projetado, ou seja, a planta de tratamento dos esgotos foi projetada em 1983 para uma capacidade de 500 ligações domiciliares e opera hoje com 1173 ligações. Portanto, o tratamento acontece de maneira parcial devido à situação de sobrecarga a partir de 1993. De qualquer forma, a estação de tratamento é um campo de pesquisa ímpar, pois continua recebendo os esgotos brutos do centro urbano ininterruptamente, o que permite avaliar os efeitos da disposição de esgotos por um período de 20 anos. No presente estudo os dados avaliados referem-se ao ano de 2000.

O tratamento é constituído por gradeamento, desarenamento, seguidos de quatro módulos de disposição com dimensôes individuais de $25 \mathrm{~m}$ de largura por $70 \mathrm{~m}$ de comprimento e $2 \%$ de declividade, configurando-se assim os quatro planos inclinados, nos quais a massa líquida escoa pelo cultivo de gramíneas, onde se efetiva o tratamento propriamente dito. Em seguida, o efluente é recolhido em canaletas de coleta, dispostas a jusante dos referidos planos inclinados, e encaminhado ao corpo receptor. A estação de tratamento dista $1.200 \mathrm{~m}$ do centro urbano e lança seus efluentes no córrego Vista Alegre, conforme mostra a Figura 2 (Paganini, 1997; Terada et al., 1985).

Cada módulo recebe esgotos por um dia, permanecendo três dias em secagem. A taxa de aplicação, definida como sendo a vazão distribuída por unidade de largura dos módulos, é de $0,7432 \mathrm{~m}^{3} /$ hora $\mathrm{x}$ m e a taxa de aplicação superficial é de $6,36 \mathrm{~cm} /$ dia.

\section{Localização dos pontos de coleta de solo}

Para avaliação dos efeitos da disposição de esgotos no solo, coletaram-se amostras em 7 pontos distintos no módulo I, conforme Figura 3:

- P0 - ponto testemunha, localizado fora dos módulos de tratamento, no terreno natural; 


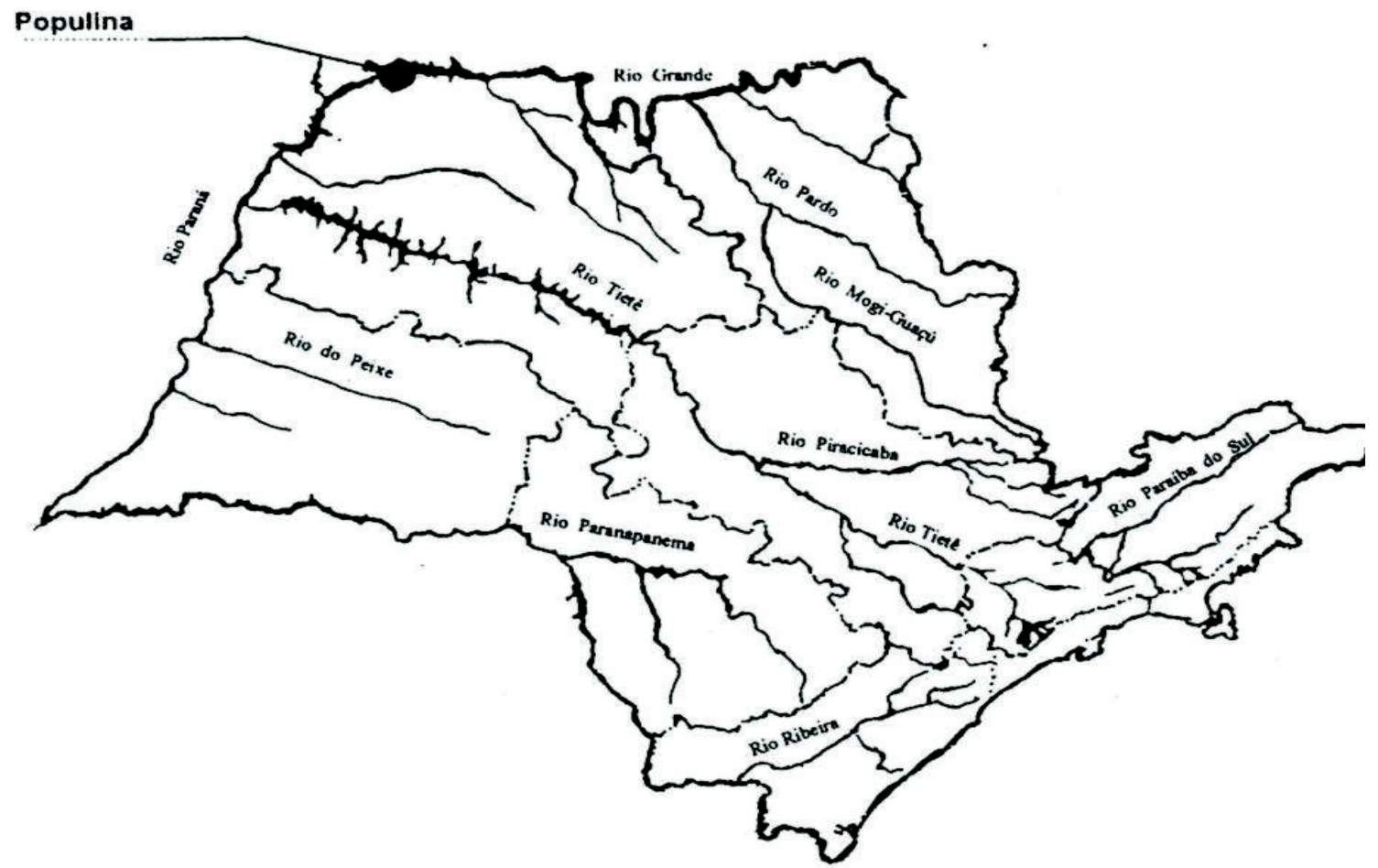

Figura I - Localização do município de Populina no Estado de São Paulo

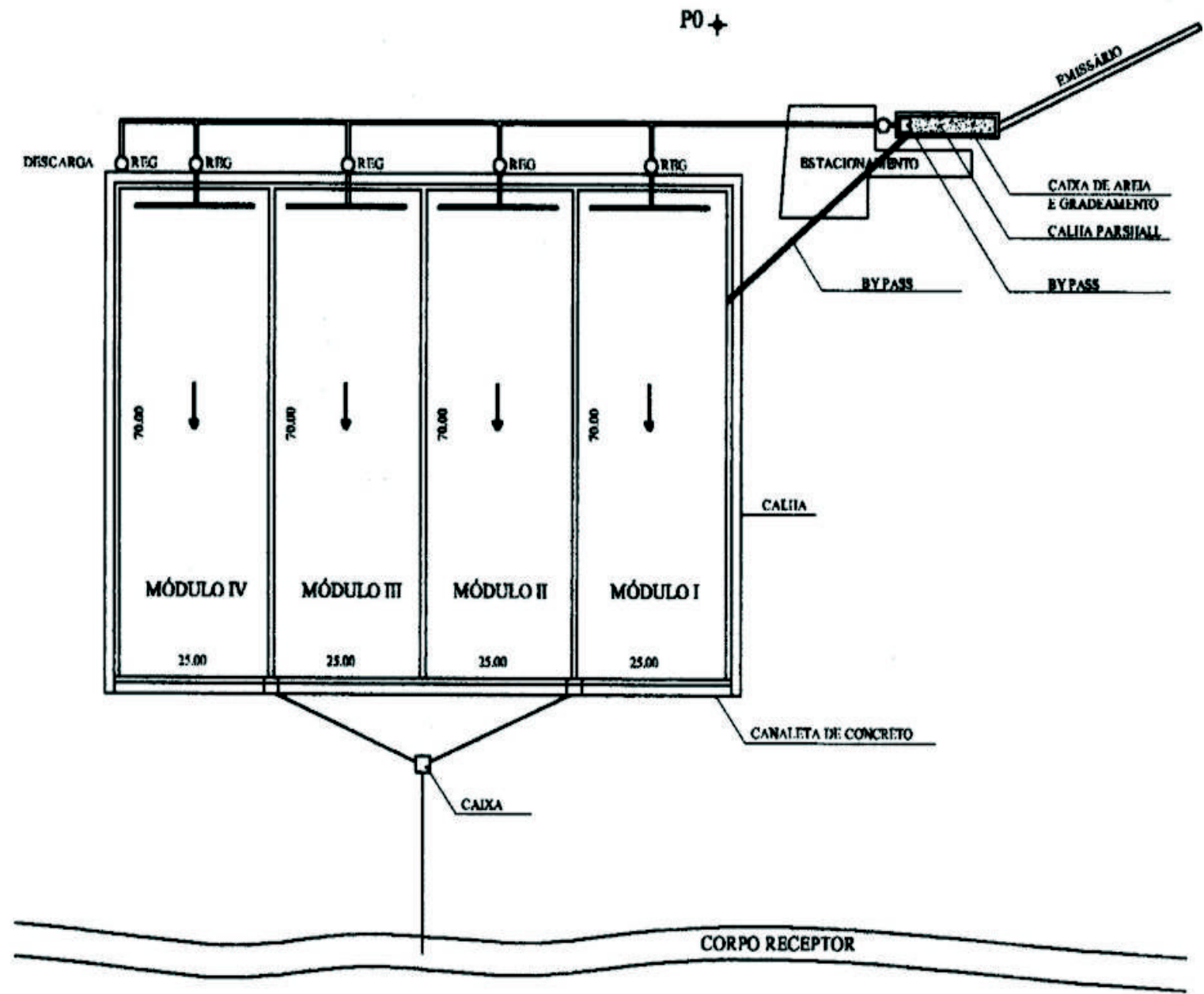

Figura 2 - Croqui da estação de tratamento de esgotos de Populina 
- P1 - ponto localizado dentro do módulo, junto ao ponto de aplicação, ou seja, este ponto recebe o esgoto afluente à estação, após o gradeamento e a caixa de areia;

- P2 - ponto localizado dentro do módulo, $10 \mathrm{~m}$ a jusante do ponto de aplicação;

- P3 - ponto localizado dentro do módulo, $20 \mathrm{~m}$ a jusante do ponto de aplicação;

- P4 - ponto localizado dentro do módulo, $30 \mathrm{~m}$ a jusante do ponto de aplicação;

- P5 - ponto localizado dentro do módulo, $50 \mathrm{~m}$ a jusante do ponto de aplicação;

- P6 - ponto localizado dentro do módulo, $70 \mathrm{~m}$ a jusante do ponto de aplicação, ou seja, este ponto corresponde ao esgoto tratado, o efluente da estação.

\section{Amostragem e Análises}

As amostras foram coletadas conforme recomenda a EMBRAPA em seu "Manual de Métodos de Análise de Solo" (EMBRAPA, 1997) e desta forma, para cada ponto descrito anteriormente, foram coletadas amostras de solo em nove profundidades diferentes, conforme estabelecido a seguir:

- De $0 \mathrm{~cm}$ (superfície) a $5 \mathrm{~cm}$

- De $5 \mathrm{~cm}$ a $10 \mathrm{~cm}$

- De $10 \mathrm{~cm}$ a $15 \mathrm{~cm}$

- De $15 \mathrm{~cm}$ a $20 \mathrm{~cm}$

- De $20 \mathrm{~cm}$ a $25 \mathrm{~cm}$

- De $25 \mathrm{~cm}$ a $30 \mathrm{~cm}$

- De $30 \mathrm{~cm}$ a $60 \mathrm{~cm}$

- De $60 \mathrm{~cm}$ a $90 \mathrm{~cm}$

- De $90 \mathrm{~cm}$ a $120 \mathrm{~cm}$

Na Figura 4 pode-se observar o detalhe de uma trincheira para coleta de amostras, nas profundidades mencionadas.

As análises de solo seguiram os padrôes recomendados pelos "Métodos de análise de solo para fins de fertilidade" (Raiji \& Quaggio, 1983), bem como as análises para detectar as concentraçôes de metais pesados, realizadas com espectrofotômetro de absorção atômica. Na presente avaliação foram analisados os seguintes parâmetros: $\mathrm{pH}$, cobre, zinco, alumínio, cádmio, mercúrio, molibdênio, níquel e chumbo.

O levantamento e análise de dados da estação têm sido realizados, durante esses 20 anos de operação, de maneira pontual ou dispersa. Sistematicamente,
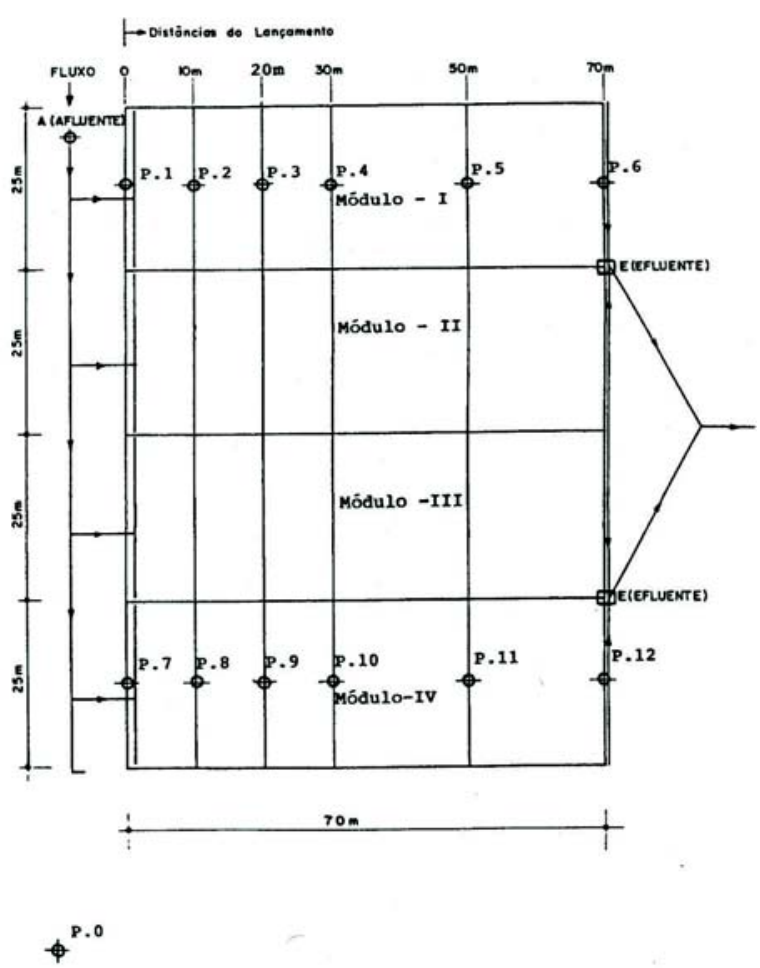

Figura 3 - Localização dos pontos de coleta (P0 a P6)
no módulo I da estação de tratamento de Populina

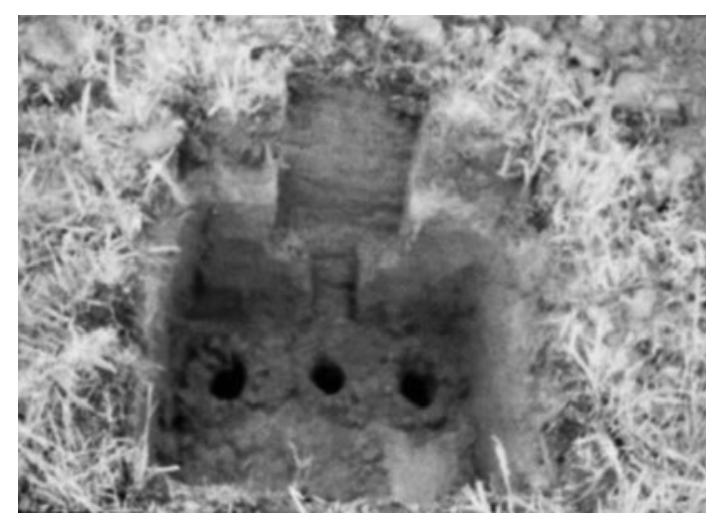

\section{Figura 4 - Detalhe de uma trincheira com amostras já coletadas para análises químicas do solo, nas diferentes profundidades}

esta foi a única campanha promovida. Entretanto, o que se tem verificado é que os resultados não apresentam discrepâncias significativas e, além disso, para que pudessem ser comparados, buscando identificar eventuais inconsistências, foram realizadas avaliaçōes em diversas profundidades e diversos pontos da planta. O trabalho completo consistiu de coletas nos módulos I e IV, porém, serão apresentados e discutidos os dados e resultados obtidos com as amostras coletadas no módulo I, considerando-se que os resultados foram muito semelhantes aos do módulo IV, com exceção do ponto P3, conforme será comentado nas conclusōes finais.

\section{RESULTADOS}

Serão apresentados, a seguir, os resultados obtidos para os metais pesados e para o $\mathrm{pH}$, nas análises do solo, para que se possa verificar seu comportamento no módulo I, nas diferentes profundidades.

\section{Cobre}

Os valores de cobre estão inseridos na Tabela 1 e Figura 5. Os valores mais elevados foram encontrados até os primeiros $20 \mathrm{~m}$ de distância do ponto de lançamento (até o P3), concentrando-se nos primeiros $15 \mathrm{~cm}$ de profundidade. 
Abaixo de $15 \mathrm{~cm}$, as maiores concentrações foram registradas no $\mathrm{P} 4$, ou seja, a $30 \mathrm{~m}$ do ponto de aplicação. É possível perceber a redução dos valores no P6 (efluente) em relação ao ponto de lançamento $\mathrm{P} 1$, exceto nos últimos $30 \mathrm{~cm}$ de profundidade.

\section{Zinco}

As concentrações mais elevadas de zinco foram verificadas até $20 \mathrm{~m}$ de distância do ponto de aplicação (até o P3) e até $20 \mathrm{~cm}$ de profundidade. Os valores encontrados no P6 foram bastante inferiores aos do P1, exceto na profundidade de 90 a $120 \mathrm{~cm}$ (Tabela 2 e Figura 6).

\section{Alumínio}

Concentraçóes mais elevadas de alumínio foram verificadas nos pontos 2 e 3 , até $20 \mathrm{~cm}$ de profundidade. Os resultados encontram-se na Tabela 3 e Figura 7.

\section{Cádmio}

As concentrações de cádmio foram mais elevadas no P3 (a 20 m de distância do ponto de lançamento). Observou-se também a concentração um pouco mais elevada deste elemento no P6 na profundidade de 90 a $120 \mathrm{~cm}$. (Tabela 4 e Figura 8).

\section{Mercúrio}

Os valores mais elevados $(3,71 \mathrm{mg} / \mathrm{L}$ e 3,39 mg/L) foram registrados a $20 \mathrm{~m}$ do ponto de lançamento, no P3. Os resultados encontram-se na Tabela 5 e Figura 9.

\section{Molibdênio}

Os resultados encontram-se na Tabela 6 e Figura 10. O valor mais elevado foi verificado no P3, a $20 \mathrm{~m}$ de ponto de lançamento, na profundidade de $10 \mathrm{a}$ $15 \mathrm{~cm}(0,63 \mathrm{mg} / \mathrm{L})$.

\section{Níquel}

O valor mais elevado na superfície foi obtido a $10 \mathrm{~m}$ do ponto de lançamento do esgoto (P2). Para as demais profundidades, as concentrações mais elevadas de níquel foram verificadas a $20 \mathrm{~m}$ do ponto de lançamento (P3), conforme mostra a Tabela 7 e a Figura 11.

\section{Chumbo}

Níveis elevados de chumbo foram encontrados, principalmente, na faixa de
10 a 30 m de distância do ponto de lançamento dos esgotos (até o P3) e, mais acentuadamente, até aos $15 \mathrm{~cm}$ de profundidade (Tabela 8 e Figura 12).

Tabela I - Concentrações de cobre em relação ao ponto de lançamento dos esgotos e à profundidade no módulo I (mg/L)

\begin{tabular}{cccccccc}
\hline Profundidade $(\mathrm{cm})$ & P0 & P1 & P2 & P3 & P4 & P5 & P6 \\
\hline $0-5$ & 0,6 & 24,6 & 60,4 & 65,5 & 16,8 & 1,8 & 0,9 \\
$5-10$ & 0,6 & 10,2 & 36,9 & 17,1 & 8,9 & 1,4 & 1,1 \\
$10-15$ & 0,7 & 12,0 & 9,5 & 6,8 & 4,3 & 3,6 & 1,3 \\
$15-20$ & 0,7 & 4,1 & 6,8 & 3,9 & 9,7 & 2,5 & 3,2 \\
$20-25$ & 0,5 & 5,2 & 5,8 & 6,2 & 11,9 & 2,2 & 0,5 \\
$25-30$ & 0,5 & 6,4 & 7,5 & 6,2 & 7,5 & 2,0 & 0,5 \\
$30-60$ & 0,8 & 9,5 & 5,9 & 5,7 & 6,1 & 1,3 & 5,5 \\
$60-90$ & 0,5 & 6,5 & 1,9 & 6,8 & 13,6 & 4,5 & 2,6 \\
$90-120$ & 0,4 & 4,6 & 2,2 & 6,8 & 12,1 & 5,5 & 18,0 \\
\hline
\end{tabular}

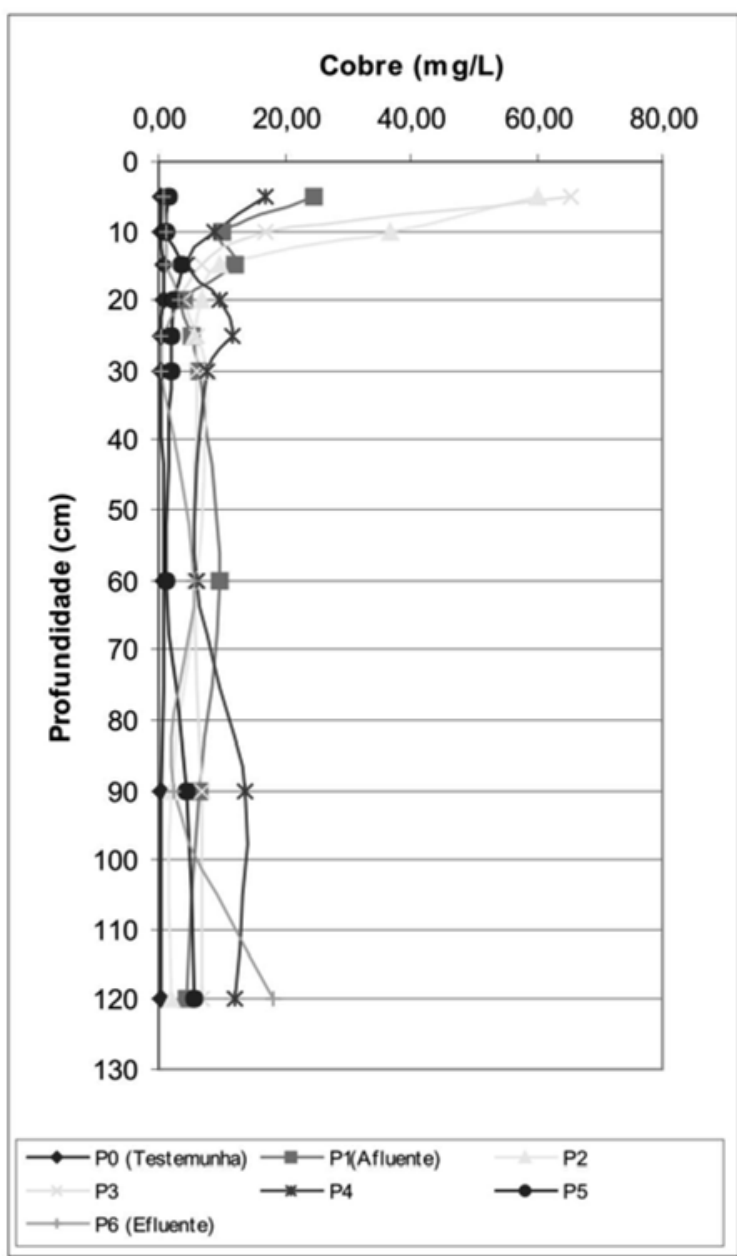

Figura 5 - Redução das concentrações de cobre em relação ao ponto de lançamento dos esgotos e à profundidade no módulo I 
Tabela 2 - Concentrações de zinco em relação ao ponto de lançamento dos esgotos e à profundidade no módulo I (mg/L)

\begin{tabular}{cccccccc}
\hline Profundidade $(\mathrm{cm})$ & P0 & P1 & P2 & P3 & P4 & P5 & P6 \\
\hline $0-5$ & 3,3 & 37,6 & 27,7 & 30,1 & 26,4 & 27,1 & 13,9 \\
$5-10$ & 0,9 & 43,6 & 51,5 & 27,7 & 42,6 & 9,6 & 2,0 \\
$10-15$ & 0,5 & 49,8 & 38,9 & 34,3 & 19,8 & 7,6 & 1,3 \\
$15-20$ & 1,0 & 11,9 & 18,8 & 18,5 & 13,2 & 4,6 & 2,3 \\
$20-25$ & 0,4 & 10,2 & 10,6 & 19,8 & 9,9 & 2,6 & 0,4 \\
$25-30$ & 0,2 & 8,5 & 7,8 & 14,5 & 5,9 & 2,1 & 0,3 \\
$30-60$ & 0,1 & 7,3 & 4,2 & 9,9 & 5,4 & 1,5 & 3,6 \\
$60-90$ & 0,1 & 5,5 & 1,3 & 6,5 & 8,7 & 4,0 & 2,2 \\
$90-120$ & 0,0 & 3,6 & 1,7 & 4,6 & 8,7 & 5,0 & 14,2 \\
\hline
\end{tabular}

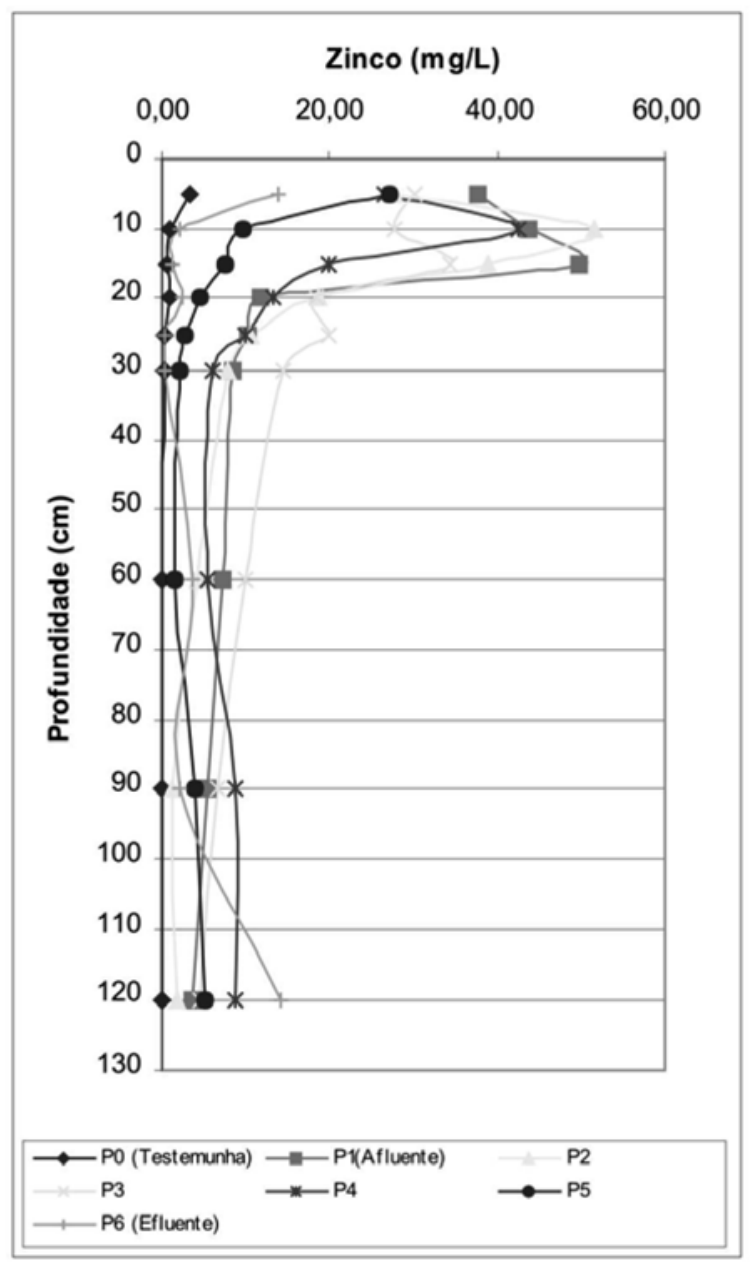

Figura 6 - Redução das concentrações de zinco em relação ao ponto de lançamento dos esgotos e à profundidade no módulo I 
Paganini, S. W., Souza, A., Bocchiglieri, M. M.

Tabela 3 - Concentrações de alumínio em relação ao ponto de lançamento dos esgotos e à profundidade no módulo I ( $\mathrm{mg} / \mathrm{L})$

\begin{tabular}{cccccccc}
\hline Profundidade $(\mathrm{cm})$ & P0 & P1 & P2 & P3 & P4 & P5 & P6 \\
\hline $0-5$ & 2,02 & 3,90 & 268,77 & 0,51 & 7,72 & 4,25 & 2,76 \\
$5-10$ & 24,80 & 41,05 & 6,62 & 55,10 & 4,79 & 22,77 & 14,18 \\
$10-15$ & 115,82 & 32,44 & 15,75 & 158,35 & 13,71 & 15,42 & 7,70 \\
$15-20$ & 150,70 & 2,17 & 2,26 & 76,79 & 2,09 & 16,81 & 5,36 \\
$20-25$ & 130,71 & 1,39 & 1,32 & 12,28 & 2,17 & 23,36 & 8,26 \\
$25-30$ & 127,89 & 0,19 & 0,88 & 7,19 & 0,74 & 21,26 & 9,13 \\
$30-60$ & 32,93 & 0,00 & 0,00 & 10,72 & 2,86 & 8,24 & 7,02 \\
$60-90$ & 50,33 & 0,10 & 0,10 & 7,46 & 0,19 & 3,90 & 9,41 \\
$90-120$ & 23,53 & 0,21 & 0,00 & 0,00 & 1,48 & 0,32 & 1,15 \\
\hline
\end{tabular}

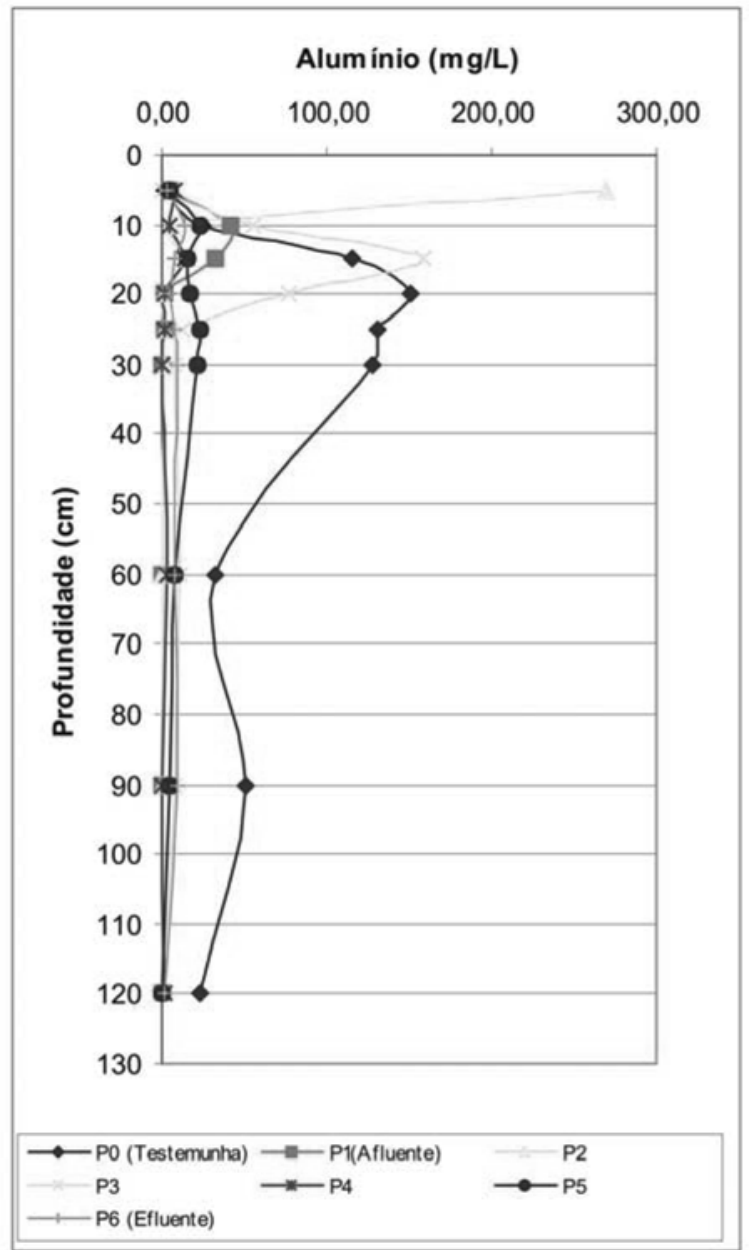

Figura 7 - Redução das concentrações de alumínio em relação ao ponto de lançamento dos esgotos e à profundidade no módulo I 
Tabela 4 - Concentrações de cádmio em relação ao ponto de lançamento dos esgotos e à profundidade no módulo I ( $\mathrm{mg} / \mathrm{L})$

\begin{tabular}{cccccccc}
\hline Profundidade $(\mathrm{cm})$ & P0 & P1 & P2 & P3 & P4 & P5 & P6 \\
\hline $0-5$ & 0,11 & 0,25 & 9,55 & 0,14 & 0,34 & 0,04 & 0,04 \\
$5-10$ & 0,01 & 1,12 & 0,49 & 1,64 & 0,08 & 0,31 & 0,04 \\
$10-15$ & 0,00 & 1,80 & 1,02 & 4,10 & 0,46 & 0,19 & 0,00 \\
$15-20$ & 0,02 & 0,21 & 0,47 & 2,44 & 0,17 & 0,19 & 0,00 \\
$20-25$ & 0,00 & 0,15 & 0,27 & 2,03 & 0,08 & 0,07 & 0,00 \\
$25-30$ & 0,05 & 0,02 & 0,12 & 1,34 & 0,08 & 0,17 & 0,04 \\
$30-60$ & 0,08 & 0,03 & 0,05 & 1,26 & 0,07 & 0,08 & 0,01 \\
$60-90$ & 0,06 & 0,01 & 0,07 & 0,47 & 0,02 & 0,19 & 0,00 \\
$90-120$ & 0,00 & 0,01 & 0,03 & 0,07 & 0,05 & 0,03 & 0,09 \\
\hline
\end{tabular}

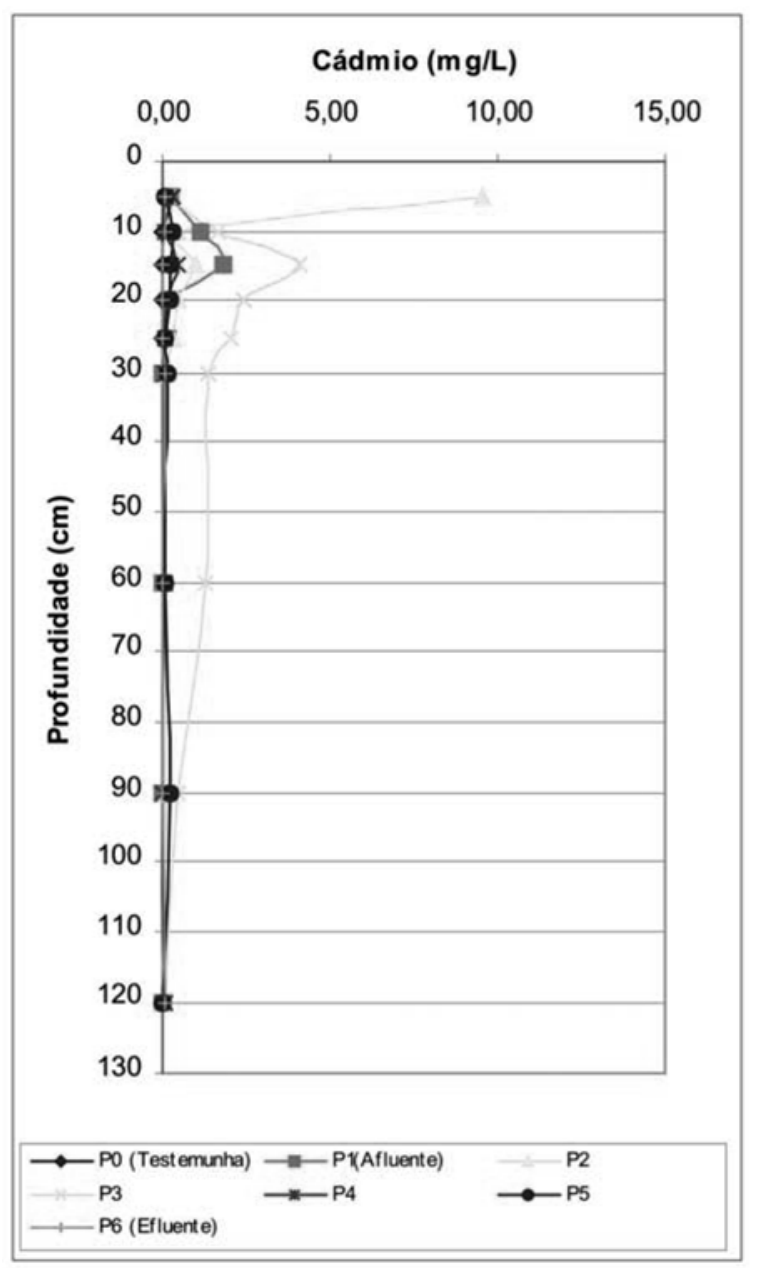

Figura 8 - Redução das concentrações de cádmio em relação ao ponto de lançamento dos esgotos e à profundidade no módulo I 
Paganini, S. W., Souza, A., Bocchiglieri, M. M.

Tabela 5 - Concentrações de mercúrio relação ao ponto de lançamento dos esgotos e à profundidade no módulo I (mg/L).

\begin{tabular}{cccccccc}
\hline Profundidade $(\mathrm{cm})$ & P0 & P1 & P2 & P3 & P4 & P5 & P6 \\
\hline $0-5$ & 0,00 & 0,18 & 0,00 & 0,50 & 0,63 & 0,03 & 0,03 \\
$5-10$ & 0,00 & 0,28 & 0,26 & 0,88 & 0,07 & 0,86 & 0,09 \\
$10-15$ & 0,00 & 0,00 & 0,49 & 0,00 & 0,37 & 0,00 & 0,50 \\
$15-20$ & 0,00 & 0,00 & 0,24 & 3,39 & 0,57 & 0,00 & 0,07 \\
$20-25$ & 0,00 & 0,14 & 0,26 & 1,15 & 0,38 & 0,47 & 0,00 \\
$25-30$ & 0,00 & 0,03 & 0,14 & 1,01 & 0,00 & 0,50 & 0,00 \\
$30-60$ & 0,00 & 0,29 & 0,36 & 2,04 & 0,19 & 0,00 & 0,32 \\
$60-90$ & 0,00 & 0,01 & 0,00 & 3,71 & 0,03 & 0,55 & 0,00 \\
$90-120$ & 0,00 & 0,00 & 0,00 & 1,56 & 0,00 & 0,00 & 0,00 \\
\hline
\end{tabular}

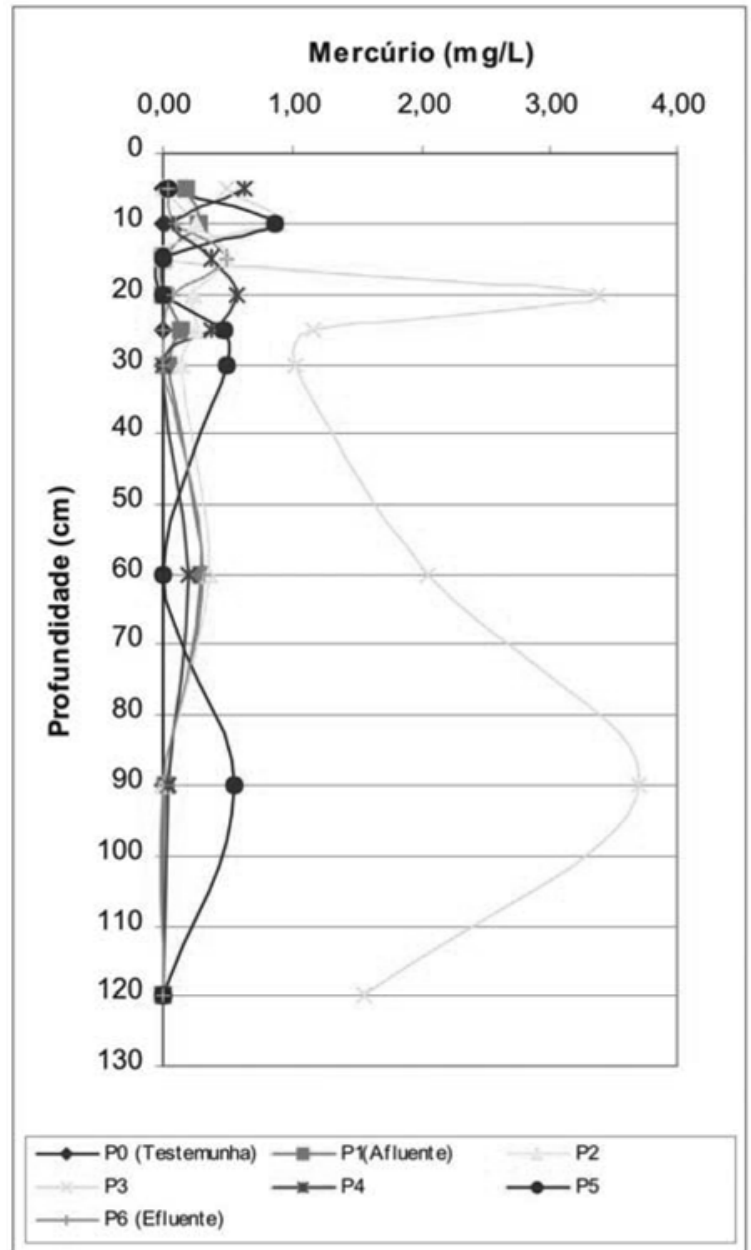

Figura 9 - Redução das concentrações de mercúrio em relação ao ponto de lançamento dos esgotos e à profundidade no módulo I 
Tabela 6 - Concentrações de molibdênio em relação ao ponto de lançamento dos esgotos e à profundidade no módulo I (mg/L)

\begin{tabular}{cccccccc}
\hline Profundidade $(\mathrm{cm})$ & P0 & P1 & P2 & P3 & P4 & P5 & P6 \\
\hline $0-5$ & 0,00 & 0,00 & 0,00 & 0,04 & 0,00 & 0,00 & 0,00 \\
$5-10$ & 0,08 & 0,00 & 0,00 & 0,00 & 0,00 & 0,00 & 0,00 \\
$10-15$ & 0,06 & 0,00 & 0,00 & 0,63 & 0,00 & 0,00 & 0,00 \\
$15-20$ & 0,00 & 0,00 & 0,00 & 0,00 & 0,29 & 0,00 & 0,06 \\
$20-25$ & 0,00 & 0,00 & 0,00 & 0,00 & 0,00 & 0,00 & 0,00 \\
$25-30$ & 0,00 & 0,00 & 0,04 & 0,00 & 0,00 & 0,00 & 0,00 \\
$30-60$ & 0,05 & 0,00 & 0,00 & 0,00 & 0,00 & 0,00 & 0,26 \\
$60-90$ & 0,04 & 0,01 & 0,21 & 0,00 & 0,00 & 0,00 & 0,00 \\
$90-120$ & 0,17 & 0,00 & 0,06 & 0,16 & 0,00 & 0,00 & 0,00 \\
\hline
\end{tabular}

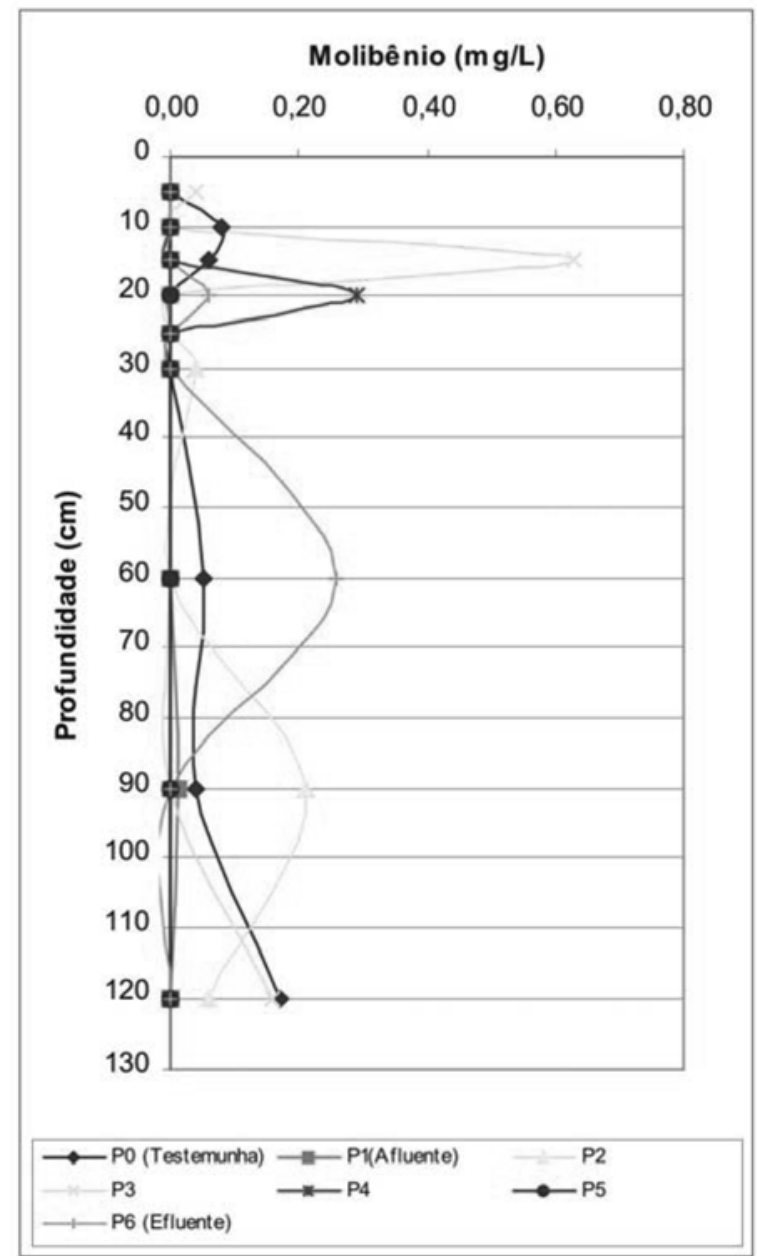

Figura 10 - Redução das concentrações de molibdênio em relaçãa ao ponto de lançamento dos esgotos e à profundidade no módulo I 
Paganini, S. W., Souza, A., Bocchiglieri, M. M.

Tabela 7 - Concentrações de níquel em relação ao ponto de lançamento dos esgotos e à profundidade no módulo I (mg/L)

\begin{tabular}{cccccccc}
\hline Profundidade $(\mathrm{cm})$ & P0 & P1 & P2 & P3 & P4 & P5 & P6 \\
\hline $0-5$ & 0,31 & 1,36 & 33,58 & 0,93 & 2,34 & 0,49 & 0,45 \\
$5-10$ & 0,99 & 5,57 & 1,70 & 7,07 & 0,74 & 3,17 & 2,66 \\
$10-15$ & 1,00 & 6,71 & 4,80 & 14,59 & 4,54 & 2,47 & 1,77 \\
$15-20$ & 0,80 & 2,43 & 3,54 & 10,04 & 0,16 & 2,75 & 1,31 \\
$20-25$ & 0,36 & 2,36 & 2,40 & 11,52 & 1,96 & 1,66 & 0,95 \\
$25-30$ & 0,70 & 0,25 & 1,12 & 11,63 & 1,65 & 1,63 & 0,67 \\
$30-60$ & 0,23 & 1,62 & 0,10 & 7,91 & 1,17 & 1,14 & 0,40 \\
$60-90$ & 0,60 & 0,12 & 0,15 & 3,70 & 0,13 & 1,67 & 1,12 \\
$90-120$ & 0,50 & 0,06 & 0,08 & 1,70 & 1,00 & 0,21 & 1,52 \\
\hline
\end{tabular}

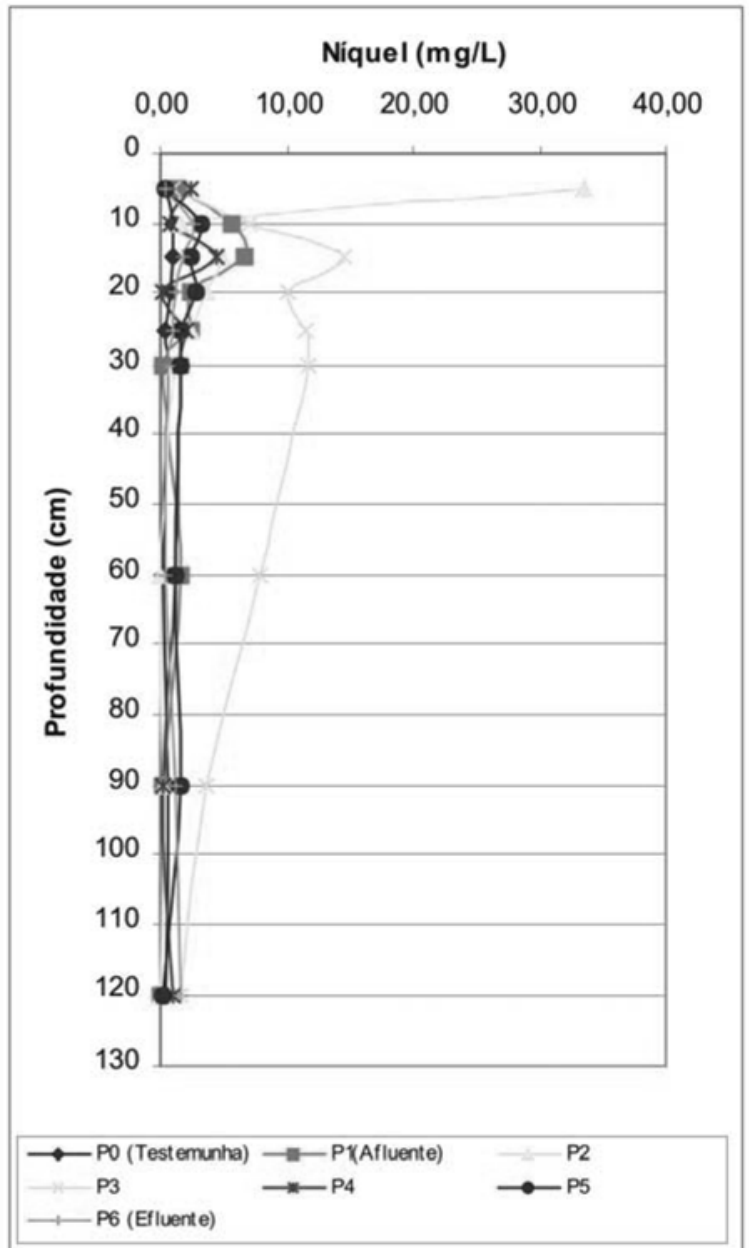

Figura I I - Redução das concentrações de níquel em relação ao ponto de lançamento dos esgotos e à profundidade no módulo I 
Tabela 8 - Concentrações de chumbo em relação ao ponto de lançamento dos esgotos e à profundidade no módulo I (mg/L)

\begin{tabular}{cccccccc}
\hline Profundidade $(\mathrm{cm})$ & P0 & P1 & P2 & P3 & P4 & P5 & P6 \\
\hline $0-5$ & 4,20 & 6,94 & 189,07 & 1,26 & 5,79 & 1,48 & 1,08 \\
$5-10$ & 4,94 & 53,38 & 10,36 & 0,04 & 3,25 & 6,58 & 5,40 \\
$10-15$ & 5,06 & 42,90 & 20,60 & 106,98 & 9,09 & 3,72 & 4,94 \\
$15-20$ & 4,36 & 6,14 & 6,24 & 39,78 & 5,24 & 3,84 & 3,58 \\
$20-25$ & 3,97 & 6,60 & 7,07 & 27,41 & 5,18 & 2,98 & 3,51 \\
$25-30$ & 5,63 & 0,60 & 3,12 & 21,62 & 4,46 & 3,61 & 4,07 \\
$30-60$ & 6,79 & 5,84 & 0,00 & 30,27 & 7,11 & 4,11 & 4,06 \\
$60-90$ & 5,87 & 0,60 & 0,97 & 27,24 & 0,92 & 7,01 & 9,53 \\
$90-120$ & 8,65 & 0,55 & 0,75 & 13,40 & 7,59 & 0,84 & 10,71 \\
\hline
\end{tabular}

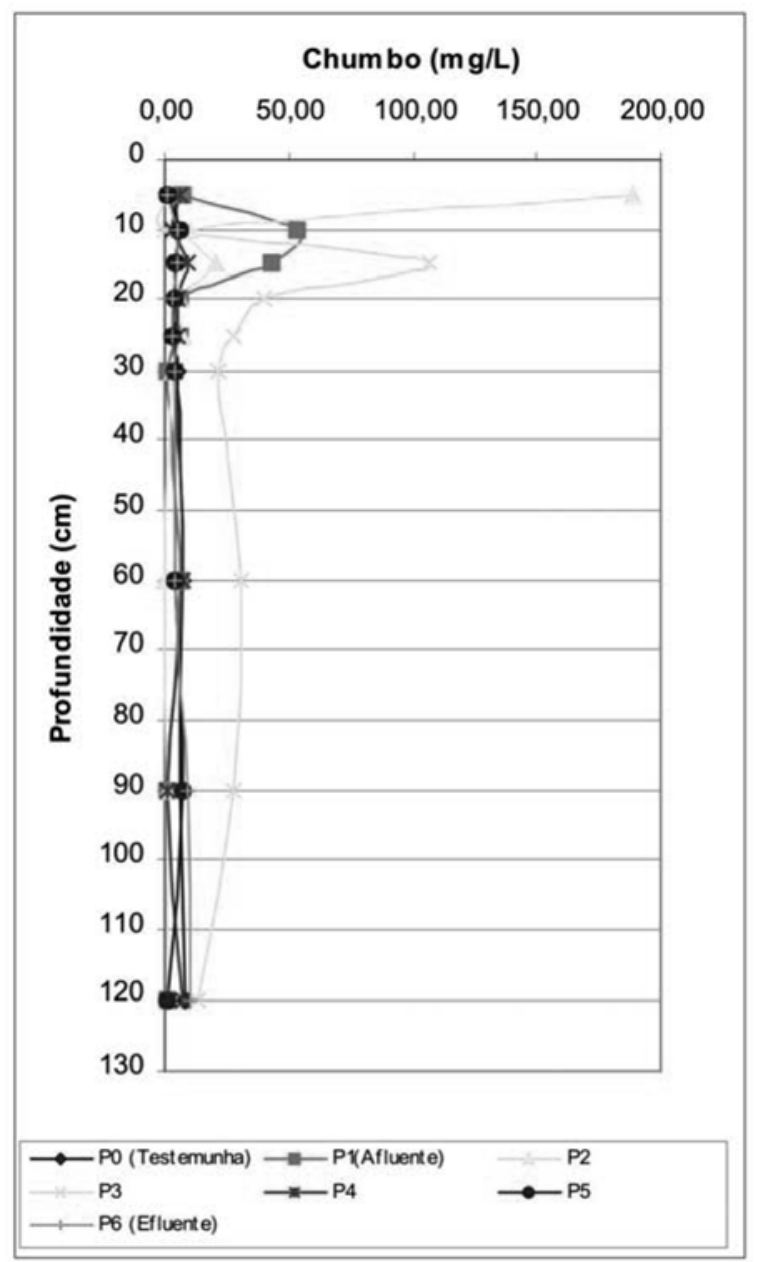

Figura I 2 - Redução das concentrações de chumbo em relação ao ponto de lançamento dos esgotos e à profundidade no módulo I 


\section{$\mathrm{pH}$}

Os valores considerados muito baixos para o $\mathrm{pH}$ dos solos são aqueles abaixo de 4,3; os baixos estão na faixa de 4,4 a 5,0; os médios entre 5,1 a 5,5; os altos de 5,6 a 6,0 e, acima de 6,0 muito altos. Assim, os valores encontrados no ponto testemunha foram de médios a baixos e, os verificados nos pontos de controle, de baixos e médios a altos, conforme a Tabela 9.

\section{DISCUSSÃO}

O presente estudo não teve, por objetivo, avaliar o processo de tratamento de esgotos por disposição no solo, e sim verificar os efeitos da utilização da área para tal finalidade, durante 16 anos, verificando o comportamento dos metais no solo, para subsidiar avaliaçôes em relação aos eventuais prejuízos ao meio ambiente.

$\mathrm{Nas}$ pesquisas realizadas em Populina (Paganini, 2001), não foram detectadas concentraçôes de metais pesados no corpo receptor, exceto para o níquel e alumínio que apresentaram, concentraçôes de, respectivamente, $0,030 \mathrm{mg} / \mathrm{L}$ e $0,001 \mathrm{mg} / \mathrm{L}$, que não ultrapassam os limites estabelecidos pelo Decreto Estadual no 8468 para o corpo receptor (Classe 2). Nessa mesma pesquisa, não foram encontrados os metais chumbo, alumínio e mercúrio nos vegetais colhidos nos pontos de controle dentro dos módulos de disposição. Já o cádmio e o níquel apresentaram resultados de concentraçôes mais elevadas nas parcelas vegetais colhidas dentro dos módulos em relação àquelas do ponto testemunha ( $\mathrm{P} 0$ ), indicando, assim, a possibilidade de que o vegetal que recebeu a disposição dos esgotos tenha absorvido esses metais pesados. Na caracterização do esgoto afluente à estação, o zinco apresentou $0,174 \mathrm{mg} / \mathrm{L}$ de concentração e todos os outros metais não foram detectados pela metodologia de análise adotada.

Conforme foi mencionado anteriormente, teoricamente o cobre e o zinco, em concentraçôes acima $10 \mathrm{mg} / \mathrm{L}$, podem vir a ser tóxicos às plantas. Em Populina, concentraçôes muito acima deste limite foram detectadas, sem que os efeitos tóxicos fossem verificados.

Neste trabalho, poucos valores de $\mathrm{pH}$ se apresentaram menores que 5,0, sendo estes de 4,7 a 4,9. O alumínio não se apresentou tóxico à vegetação, como é esperado para valores de $\mathrm{pH}$ menores que 5,5 . Os baixos níveis de alumínio propi-

Tabela 9 - Valores de pH em relação aos pontos de lançamento dos esgotos e à profundidade no módulo I

\begin{tabular}{cccccccc}
\hline Profundidade $(\mathrm{cm})$ & P0 & P1 & P2 & P3 & P4 & P5 & P6 \\
\hline $0-5$ & 5,2 & 5,4 & 4,8 & 4,9 & 4,9 & 4,9 & 5,1 \\
$5-10$ & 4,9 & 4,8 & 5,0 & 5,0 & 5,2 & 5,0 & 5,3 \\
$10-15$ & 4,6 & 4,7 & 5,2 & 5,1 & 5,3 & 5,2 & 5,5 \\
$15-20$ & 4,5 & 5,2 & 5,4 & 5,2 & 5,4 & 5,2 & 5,6 \\
$20-25$ & 4,6 & 5,2 & 5,4 & 5,1 & 5,6 & 5,3 & 5,6 \\
$25-30$ & 4,5 & 5,1 & 5,7 & 5,3 & 5,5 & 5,2 & 5,6 \\
$30-60$ & 4,6 & 5,5 & 5,6 & 5,2 & 5,4 & 5,3 & 5,0 \\
$60-90$ & 4,5 & 6,0 & 6,0 & 5,1 & 5,3 & 5,4 & 4,5 \\
$90-120$ & 4,5 & 5,9 & 5,9 & 5,5 & 5,5 & 5,2 & 4,3 \\
\hline
\end{tabular}

ciaram a discreta elevação dos valores de pH observados com o aumento da profundidade, em todos os pontos. No ponto testemunha, o $\mathrm{pH}$ foi se reduzindo, em relação à profundidade, pelas razōes opostas as acima descritas.

Todos os pontos amostrados, com exceção do P3, apresentaram ausência de mercúrio abaixo de $90 \mathrm{~cm}$ de profundidade, não apresentando ameaça ao lençol subterrâneo.

Fato não esperado e que apareceu nas medições, foram os níveis de chumbo encontrados, principalmente, na faixa de 10 a 30 metros de distância do ponto de lançamento dos esgotos e, mais acentuadamente até aos $15 \mathrm{~cm}$ de profundidade.

\section{CONCLUSÕES}

Com os resultados obtidos, é possível concluir que a grande maioria dos metais pesados apresentou comportamento semelhante, com concentraçôes elevadas no trecho que vai do ponto de lançamento até a distância de 30 e 50 m deste ponto inicial, sendo que a maioria destes metais pesados apresentou concentraçóes mais elevadas até a profundidade de $20 \mathrm{~cm}$.

As concentrações de chumbo medidas no ponto P0 (testemunha) foram baixas, sendo verificado um aumento dos níveis de chumbo em diversos pontos da planta. Essa variação pode ser atribuída ao despejo de dois postos de abastecimento de combustíveis na rede coletora, existentes na zona urbana de Populina que, se comparados com o número total de ligaçôes, não podem ser considerados desprezíveis.

O ponto de controle $\mathrm{P} 3$ que se localiza a $20 \mathrm{~m}$ do ponto de lançamento dos esgotos no módulo I, apresentou valores elevados de mercúrio, níquel, chumbo e alumínio em todas as profundidades. Essa verificação merece ser mais bem estudada, através de novas coletas e análises, pois, se esses valores forem confirmados, existe um grande risco de contaminação dos lençóis subterrâneos, porém isto não foi demonstrado em estudos já realizados nos aqüíferos subterrâneos (Paganini,2001).

Não foram observados efeitos fitotóxicos às plantas, ainda que o cobre e o zinco apresentassem concentraçóes no solo acima do limite de toxicidade. Isto pode ser creditado à sinergia causada pela elevada diversidade dos elementos presentes no meio, o que possibilita às plantas sobreviverem com a absorção seletiva do que necessitam e não lhes é tóxico.

Dos resultados obtidos nas avaliações, pode-se considerar que a estação de tratamento, mesmo nesta situação de sobrecarga, ainda está funcionando relativamente bem como uma barreira sanitária em relação ao ecossistema local, com vantagens sobre os sistemas de tratamento convencionais, pois produziu biomassa de boa qualidade, a qual foi utilizada para alimentação animal, além de ter proporcionado o tratamento dos esgotos em nível terciário, pela utilização dos nutrientes no sistema solo-vegetal, mesmo nestas condiçóes desfavoráveis de subdimensionamento. 


\section{REFERÊNCIAS}

AL-WABEL, M.I.; Et. al. Effect of sewage sludge on some chemical properties of calcareous sandy soils. Commun Soil Sci Plant Anal, v. 29, p. 2713-24, 1998.

CARLSON, C.A.; HUNT, P.G.; DELANEY, T.B.J. Overland flow treatment of wastewater. Vicksburg, U.S. Army Engineer Waterways Experiment Station, 1974.

DRIVER, C.H. et al. Assessement of effectiveness and effects of land disposal methodologies of water management. Washington: Department of the Army Corps of Engineers, 1972.

EMBRAPA EMPRESA BRASILEIRA DE PESQUISA AGROPECUÁRIA. Manual de métodos de análise de solo. Centro Nacional de Pesquisa de Solos. Rio de Janeiro, 1997.

ENVIRONMENT PROTECTION AUTHORITY OF VICTORIA. Guidelines for the disposal of wastewater on land irrigation. Melbourne, (Publication, 168). 1983.

ENVIRONMENT PROTECTION AUTHORITY OF VICTORIA. Guidelines for wastewater irrigation. Melbourne, (Publication, 168). 1991.

ENVIRONMENT PROTECTION AUTHORITY OF VICTORIA. The use of transpiration beds for domestic wastewater disposal. Melbourne, (Publication, 104). 1980.

GHEYI, H.R.; QUEIROZ, J.E.; MEDEIROS, J.F. Manejo e controle da salinidade na agricultura irrigada. In: XXVI CONGRESSO BRASILEIRO DE ENGENHARIA AGRÍCOLA: 1997, Campina Grande. Anais... Paraíba: Sociedade Brasileira de Engenharia Agrícola,1997.

GUPTA, U.C., GUPTA, S.C. Trace element toxicology relationships to crop production and livestock and human health: implications for management. Commun Soil Sci Plant Anal v. 29, p. 1491-522, 1998.

JENSEN, D.L.; LEDIN, A.; CHRISTENSEN, T.H.. Speciation of heavy metals in landfillleachate polluted groundwater. Water Res. v. 33, p. 2642-50, 1999.

KANDIAH, A. Quality criteria in using sewage effluent for crop production. In: FOOD AND AGRICULTURE ORGANIZATION OF
UNITED NATIONS. Regional Seminar on the Treatment and Use of Sewage Effluent for Irrigation. Nicosia, Roma, FAO, 1985.

MANCUSO, P.C.S. Reúso de Água. São Paulo, Dissertação (Mestrado em Saúde Pública) - Universidade de São Paulo. Faculdade de Saúde Pública. 1988.

MATIAZZO-PREZOTTO, M.E. Comportamento de cobre, cádmio, cromo, níquel e zinco adicionados a solos de clima tropical em diferentes valores de $p H$. Piracicaba; Tese (Livre Docência) - Universidade de São Paulo. Escola Superior de Agricultura Luiz de Queiroz. 1994.

MCBRIDE, M.B. Growing food crops on sludgeamended soils: problems with the U.S. Environmental Protection Agency method of estimating toxic metal transfer. Environ Toxicol Chem, v.17, p.2274-81,1998.

MELBOURNE WATER CORPORATION. Melbourne water-western plant data. Melbourne, 1994.

NATIONAL RESEARCH COUNCIL. Use of reclaimed water and sludge in food crop production. Washington (DC), 1996.

PAGANINI, W.S. Disposição de esgotos no solo: escoamento à superficie. São Paulo: Fundo Editorial da AESABESP, 1997.

PAGANINI, W.S. Efeitos da disposição de esgotos no solo. São Paulo, 2001. Tese (Doutorado em Saúde Pública) - Universidade de São Paulo. Faculdade de Saúde Pública.

PAGANINI, W.S. Reúso de água na agricultura. In: MANCUSO, P.C.S.; SANTOS, H.F. (Ed.). Reúso de água. São Paulo: Manole, p. 339-401. 2003

PASPALIARIS, P., HODGSON, B. Treatment of wastewater by an overland continuous flow grass filtration sistem. In: $15^{\mathrm{TH}}$ FEDERAL CONVENTION; GOLD COAST; 1993.

POSTAFOS ASSOCIAÇÃO BRASILEIRA PARA PESQUISA DA POTASSA E DO FOSFATO. Manual internacional de fertilidade do solo/tradução e adaptação de Alfredo Scheid Lopes- $2^{\mathrm{a}}$ ed, ver e ampl. Piracicaba, 1998.

RAIJI, B. V.; QUAGGIO, J.A. Métodos de análise de solo para fins de fertilidade. Bul Tec Inst. Agron.; v. 81, p. 1-31, 1983
RAMACHANDRAN V.; D'SOUZA, T.J. Plant uptake of cadmium, zinc, and manganese in soils amended with sewage sludge and city compost. Bull Environ Contam Toxicol, v. 61, p. 347-54, 1998.

TERADA, M.; PAGANINI, W.S.; ZUCCOLO, A.C.F. Tratamento de esgotos domésticos por disposição no solo com utilização de gramíneas. Revista DAE, v.45, p. 249-54, 1985.

TSAI, T.D.; VESILIND, P.A. A new landfill liner to reduce groundwater contamination from heavy metals. J Environ Eng, v.124, p. 10615, 1998.

UNDERWOOD, E.J. Environmental sources of heavy metals and their toxicity to man and animals. In: Proceedings of the International Conference on Developments in Land Methods of Wastewater Treatment and Utilisation; Melbourne. Proceedings. Melbourne: IAWPRC, (paper n.3). 1978.

VERMA, S.R.; et. al. Evalution of an application factor for determining the safe concentration of agricultural an industrial chemicals. Water Res, v. 18 , p. $11-5,1984$.

WILLIAMS, J.H. Use of sewage on agricultural land and the effects of metals on crops. Water Pollut Control , v. 74, p. 635-44, 1975.

\section{Endereço para correspondência:}

Wanderley da Silva Paganini

Universidade de São Paulo - USP

Departamento de Saúde Ambiental

Av. Dr. Arnaldo, 7 I 5 - $I^{\circ}$ andar 0I 255-000 - São Paulo - SP - Brasil

Tel.: (I I) 3066-7 I I5

Fax: (I I) 3066-7732

E-mail: paganini@usp.br

\title{
$23^{\circ}$ Congresso Brasileiro de Engenharia Sanitária e Ambiental
}

\author{
Setembro de 2005 - Campo Grande - MS
}

Resumos expandidos: até 31 de outubro de 2004 